\title{
Pure red cell aplasia and thymoma associated with high levels of the suppressor/cytotoxic $T$ lymphocyte subset
}

\author{
J P MILNES, B P GOORNEY, T B WALLINGTON
}

\begin{abstract}
A 64 year old man admitted to hospital with increasing effort dyspnoea and lethargy was found to have a thymoma and pure red cell aplasia. Lymphocytes accounted for $20-30 \%$ of marrow cells, and numbers of T8 suppressor/cytotoxic cells in peripheral blood were greatly increased. He remained anaemic after removal of the thymoma despite blood transfusions, and immunosuppression with prednisolone $60 \mathrm{mg}$ and cyclophosphamide $50 \mathrm{mg}$ daily was started. The dose of prednisolone was reduced to $15 \mathrm{mg}$ owing to steroid myopathy and the risk of opportunistic infection. He went into remission, and the dose was further decreased to $10 \mathrm{mg}$ daily.
\end{abstract}

\section{Introduction}

Cell mediated inhibition of erythropoiesis has recently been reported in patients. ${ }^{12}$ We describe the successful treatment of a patient with pure red cell aplasia and thymoma in whom extremely high numbers of $T$ lymphocytes of the $T 8$ suppressor/cytotoxic subset were found in the peripheral blood.

\section{Case report}

A previously healthy 64 year old retired docker was admitted to hospital in 1983. For two months he had suffered from increasing effort dyspnoea and lethargy. His general practitioner had diagnosed atrial fibrillation and cardiac failure and prescribed digoxin, but his

\footnotetext{
Departments of Medicine and Immunology, Southmead Hospital, Bristol BS10 5NB

J P MILNES, MRCP, registrar

B P GOORNEY, MRCP, senior house officer

T B WALLINGTON, MRCP, consultant immunologist
}

Correspondence to: Dr T B Wallington, South Western Regional Transfusion Centre, Bristol BS10 5ND. condition had not improved. Cardiac failure had persisted, and he had developed pallor.

Initial investigations showed haemoglobin concentration $4 \cdot 7 \mathrm{~g} / \mathrm{dl}$, white cell count $14 \cdot 8 \times 10^{\%} / 1$, mean corpuscular volume $119 \mathrm{fl}$, and reticulocyte count less than $1 \%$. A chest $x$ ray film showed a lobulated anterior mediastinal mass. Bone marrow examination showed greatly reduced erythropoiesis with lymphocytes accounting for $20-30 \%$ of marrow cells; megakaryocytes and granulopoiesis were normal. Lymphocyte surface marker studies were performed on cells isolated from heparinised venous blood on a Ficoll/Isopaque (Triosil) density gradient. Monoclonal antisera (Ortho) were used as follows: OKT3 (total T), OKT4 (helper/inducer T cells), and OKT8 (suppressor/ cytotoxic $\mathrm{T}$ cells). Counts were performed with an epi-illuminated fluorescence microscope. The number of OKT8 reactive cells was greatly increased with a slight reduction of OKT4 reactive cells (table). Neither antinuclear antibodies nor antiacetylcholine receptor

Tymphocyte subsets before and after treatment

\begin{tabular}{|c|c|c|c|c|c|}
\hline & $\begin{array}{c}\text { Normal } \\
\text { range }\end{array}$ & February & June & August & October \\
\hline \multirow{3}{*}{$\begin{array}{l}\text { T4 positive helper/inducer cells } \\
\left(\times 10^{\circ} / 1\right) \\
\text { T8 positive suppressor/cytotoxic } \\
\text { cells }\left(\times 10^{\circ} / 1\right) \\
4^{+}: 8^{+} \\
\text {Dosage of prednisolone }(\mathrm{mg} / \text { day) } \\
\text { Dosage of cyclophosphamide } \\
\text { (mg/day) }\end{array}$} & $0.54-1.59$ & 0.36 & 0.02 & 0.20 & 0.15 \\
\hline & $\begin{array}{l}0 \cdot 29-0 \cdot 86 \\
1 \cdot 4-2 \cdot 5\end{array}$ & $\begin{array}{l}4.98 \\
0.07\end{array}$ & $\begin{array}{l}0.26 \\
0.08 \\
60\end{array}$ & $\begin{array}{l}0.73 \\
0 \cdot 27 \\
15\end{array}$ & $\begin{array}{l}0.49 \\
0.31 \\
10\end{array}$ \\
\hline & & & 50 & 50 & 50 \\
\hline
\end{tabular}

antibodies were detected. A Coombs test gave a negative result. The following were normal: urea, electrolyte, glucose, calcium, albumin, and bilirubin concentrations; alanine aminotransferase and alkaline phosphatase activities; thyroxine, immunoglobulin, $\mathrm{C} 3$, and $\mathrm{C} 4$ concentrations; immune complexes ( $\mathrm{C} 1 \mathrm{q}$ binding); and vitamin $\mathrm{B}_{12}$ and folate concentrations.

He was treated initially with digoxin, diuretics, and blood transfusion and underwent thoracotomy. An encapsulated tumour, roughly $4 \mathrm{~cm} \times 5 \mathrm{~cm} \times 6 \mathrm{~cm}$, was removed. This was a benign thymoma of predominantly spindle cell type. His postoperative progress was uneventful, but after six weeks he was again anaemic, the reticulocyte count remaining less than $1 \%$. Further blood was given and immunosuppression with prednisolone $60 \mathrm{mg}$ and cyclophosphamide $50 \mathrm{mg}$ daily started.

Two months later he was readmitted to hospital with severe proximal myopathy, anaemia, and a right lower lobe pneumonia. His 
condition improved after treatment with amoxycillin, physiotherapy, and blood transfusion. At this time a $10 \%$ reticulocytosis developed; the peripheral lymphocyte numbers including OKT4 reactive cells were extremely low. In view of the considerable risk of opportunistic infection and the steroid myopathy the dose of prednisolone was reduced to $15 \mathrm{mg}$. From that time his condition improved appreciably. No further blood transfusion was required, and in October 1983 the dose of prednisolone was reduced to $10 \mathrm{mg}$. He subsequently remained in remission taking cyclophosphamide $50 \mathrm{mg}$ plus prednisolone $10 \mathrm{mg}$ a day.

\section{Discussion}

Idiopathic acquired pure red cell aplasia is associated with thymoma in about one third to one half of cases. Its occurrence with other autoimmune disorders and reports of successful responses to thymectomy, immunosuppressive drugs, and plasmapheresis $^{3}$ have suggested an immunological basis. In some cases the suppression of erythropoiesis appears to be mediated by humoral agents, thought to be antibodies. Putative antibodies have been shown against erythropoietin and mature erythroblasts. ${ }^{3}$ Recent reports have shown that inhibition of erythropoiesis can be effected by suppressor T lymphocytes. ${ }^{12}$

Monoclonal antibodies are available to identify T cell subsets. ${ }^{4}$ The T8 positive population contains both suppressors and cytotoxic cells. Our patient had an excess of lymphocytes in his bone marrow and high numbers of $\mathrm{T} 8$ positive cells in peripheral blood before treatment. Thymectomy followed by immunosuppression with prednisolone and cyclophosphamide effected a considerable reduction in $\mathrm{T} 8$ positive cells and clinical remission. Although functional studies were not performed, we think it probable that these cells played a part in the suppression of erythropoiesis.

Bacigalupo et al indicated that in severe aplastic anaemia the detection of suppressor $\mathrm{T}$ cells in the bone marrow correlates with successful responses to immunosuppressive regimens. ${ }^{5}$ Our observation would lend support to a similar assertion regarding pure red cell aplasia.

We thank Dr I S Bailey for permission to report this case, and Dr R R Slade and Mr K Jeyasingham for their help with the clinical management.

\section{References}

1 Hoffman R, Kopel S, Hsu SD, Dainiak N, Zanjani ED. T cell chronic lymphocyte leukemia: presence in bone marrow and peripheral blood of cells that suppress

2 Nagasawa T, Abe T, Nakagawa T. Pure red cell aplasia and hypogammaglobulinemia associated with $\mathrm{Tr}$-cell chronic lymphocytic leukemia. Blood

3 Anonymous. Red cell aplasia [Editorial]. Lancet 1982;i:546-7. therapeutic applications. Clin Haematol 1982;11:631-60. Bacigalupo A, Podesta M, Van Lint MT, et al. Severe aplastic anaemia: correlation of in vitro tests with clinical response to immunosuppression in 20 patients. Br $\mathcal{F}$ Haematol $1981 ; 47: 423-33$.

(Accepted 31 August 1984)

\title{
A sensitive immunoradiometric assay for serum thyroid stimulating hormone: a replacement for the thyrotrophin releasing hormone test?
}

\author{
J SETH, H A KELlETT, G CALDWELl, V M SWEETING， G J BECKETT, S M GOW， A D TOFT
}

\begin{abstract}
The value as a thyroid function test of a new, rapid, and highly sensitive immunoradiometric assay for thyroid stimulating hormone (TSH) was assessed in 188 consecutive new patients with suspected hyperthyroidism. The diagnosis was made on clinical grounds and on the basis of serum total triiodothyronine and thyroxine concentrations and the response of TSH to thyrotrophin releasing hormone (TRH) as measured by radioimmunoassay. In all except one patient the basal TSH concentration by immunoradiometric assay predicted the response of TSH by radioimmunoassay to TRH, an undetectable value being recorded in patients with a subnormal
\end{abstract}

\footnotetext{
University Departments of Medicine and Clinical Chemistry, Royal Infirmary, Edinburgh EH3 9YW

J SETH, PHD, MCB, top grade biochemist

H A KELLETT, MRCP, lecturer

G CALDWELL, MRCP, registrar

V M SWEETING, MSC, biochemist

G J BECKETT, PHD, senior lecturer

S M GOW, BSC, biochemist

A D TOFT, MD, FRCP, senior lecture

Correspondence to: Dr A D Toft, Department of Medicine, Royal Infirmary, Edinburgh EH3 9YW.
}

response and a measurable value in those with a normal test result. This clear relation was not observed for basal TSH concentrations as measured by radioimmunoassay. In a series of 39 hospital inpatients with acute or chronic non-thyroidal illness, of whom 11 had low concentrations of total thyroxine or triiodothyronine, or both, basal TSH concentrations were detectable by both radioimmunoassay and immunoradiometric assay in all cases and were associated with normal responses to TRH.

The immunoradiometric assay for TSH, which is commercially available, may therefore obviate the need for the more time consuming TRH test and simplify the approach to thyroid function testing in patients with suspected hyperthyroidism.

\section{Introduction}

Measurement of the basal serum concentration of thyroid stimulating hormone (TSH) is an essential test in the investigation of suspected hypothyroidism. A raised concentration confirms a primary cause of the disease, while a normal or low concentration excludes it or, more rarely, indicates a pituitary or hypothalamic cause. Except in thyrotoxicosis induced by $\mathrm{TSH}$, which is extremely rare, the basal serum TSH concentration is suppressed in hyperthyroidism. These low TSH concentrations, however, are of little diagnostic value as most 